\title{
Contamination of Soil with Diesel Oil, Application of Sewage Sludge and Content of Macroelements in Oats
}

\author{
Mirosław Wyszkowski $(\mathbb{D} \cdot$ Jadwiga Wyszkowska $(\mathbb{D} \cdot$ \\ Agata Borowik (iD) - Natalia Kordala (i)
}

Received: 13 July 2020 / Accepted: 26 October 2020 /Published online: 9 November 2020

(C) The Author(s) 2020

\begin{abstract}
The aim of the study was to determine the effect of soil contamination with diesel oil $(0,5,10$ and $15 \mathrm{~mL} / \mathrm{kg}$ d.m. of soil) on the macroelement content (nitrogen, phosphorus, potassium, sodium, magnesium and calcium) in the above-ground parts of oats (Avena sativa L.). A remediation effect of sludge as a substance which reduces the negative impact of this petroleum product on its element content in oats was also evaluated. Sewage sludge was applied in doses $0,4,8$ and $12 \mathrm{~g} / \mathrm{kg}$ of soil. The macroelement content in the above-ground parts of oats depended on the soil contamination with diesel oil and on the addition of sewage sludge to the soil. Soil contamination with diesel oil caused significant changes in the content of all macroelements in the above-ground biomass of oats. Increasing doses of the petroleum product in the series without sewage sludge decreased the content of all macroelements, except phosphorus and calcium. The highest effect was observed for the content of sodium in oats. The addition of sewage sludge to the soil alleviated the negative impact of diesel oil on the chemical composition of the plants. The application of sewage sludge to soil resulted in an increase in average content of nitrogen, sodium and magnesium (as opposed to
\end{abstract}

\footnotetext{
M. Wyszkowski $(\bowtie) \cdot$ N. Kordala

Department of Environmental Chemistry, University of Warmia and Mazury in Olsztyn, Plac Łódzki 4, 10-727 Olsztyn, Poland e-mail: miroslaw.wyszkowski@uwm.edu.pl

J. Wyszkowska · A. Borowik

Department of Microbiology, University of Warmia and Mazury in Olsztyn, Plac Łódzki 3, 10-727 Olsztyn, Poland
}

phosphorus and partly calcium) in the above-ground parts of oats, compared to the series without sewage sludge.

Keywords Diesel oil $\cdot$ Sewage sludge $\cdot$ Macroelement content $\cdot$ Avena sativa $\mathrm{L}$.

\section{Introduction}

Soil is the basic environment for plant production. Soil also performs various filtering and buffering functions, retaining organic and inorganic residues and limiting the migration of toxic substances to other elements of the biosphere (Sousa et al. 2008).

Due to the widespread occurrence and use of crude oil, a particularly serious ecological problem is soil pollution by its derivatives. Petrochemical products get into soils mainly near industrial facilities and in areas where crude oil and natural gas are extracted, processed and stored (Adam et al. 2002; Clark 2003). Components of diesel oil infiltrate the soil and destroy its structure, disrupting oxygen conditions and the ability to retain water (Hussain et al. 2019). In addition, they negatively affect on the physicochemical and biochemical properties of soil, as well as decrease the production capacity (Ziółkowska and Wyszkowski 2010). There are changes in the content of macro- and microelements, usually increasing the bioaccumulation of trace elements, as a result of the impact of petroleum substances on the plant (Wyszkowski and Ziółkowska 2009; Rusin et al. 2015). Soil contamination with diesel oil causes a decrease in the 
capacity of sorption complex, as well as the ability to exchange calcium, magnesium and potassium, while limiting the availability of these macroelements to the plant (Agbogidi and Eshegbeyi 2006; Wyszkowski and Ziółkowska 2008). Petroleum hydrocarbons released into the environment lead to degradation of chlorophyll, delayed germination and disturbance of water relations and gas exchange in plants (Bona et al. 2011; Hussain et al. 2019). The group of the most dangerous petroleum xenobiotics are aliphatic, ethylene, naphthenic and aromatic hydrocarbons (Gray et al. 1994). Polycyclic aromatic hydrocarbons are persistent organic pollutants that limit plant vegetation (Jain et al. 2011). Their mechanism of toxic action consists in disrupting the functioning and permeability of cell membranes and membraneassociated enzyme systems (Abdel-Shafy and Mansour 2016).

Petroleum substances also are a significant danger to animals and humans. Oil components migrate deep into the soil and into surface and ground waters, threatening the safety of drinking water sources (Wang et al. 2008). Some of the petroleum components were sorbed on soil particles or they are moved from the roots to the aboveground parts of plants, where they can accumulate (Hunt et al. 2019). They may get to the next links in the food and trophic chain. Moreover, hydrocarbons can evaporate to the air straight from soil or from water bodies. Such vapours then have a toxic effect on the respiratory systems of living organisms (Cheng and Nathanail 2009). They have a mutagenic and carcinogenic effect on humans (Jain et al. 2011).

Petroleum-derived hydrocarbons are highly resistant to biodegradation. They also have high potential for migration and spreading in the environment (Khalilova 2015). Studies show that petroleum derivatives adversely affect plant growth after 3 (Rusin et al. 2015) and even 5 years (Inckot et al. 2011) from soil contamination. Organic substitutes in the form of municipal sewage sludge may be useful in the process of remediation of soils contaminated with these substances. Their application improves the soil physicochemical properties by increasing the organic carbon, nitrogen and phosphorus content (Moreno-Penaranda et al. 2004). The use of sludge improves the recycling of nutrients and organic matter (Kominko et al. 2018) while at the same time reducing the environmental and economic cost of its neutralization (Janowska et al. 2017). It is difficult to find the results of studies into the effect of sewage sludge on macroelement content in plants if they are used with a view to weakening the effect of diesel oil on plants. The literature refer to the application of organic matter, bentonite, zeolite and calcium oxide to neutralize other contaminants, e.g. heavy metals.

This study aimed to determine the impact of soil contamination with diesel oil on the chemical composition of the above-ground parts of oats (Avena sativa L.). The plants were grown in uncontaminated (control) and contaminated soil. An effect of sewage sludge as a substance which reduces the negative impact of this petroleum product the macroelement content in the above-ground parts of oats was also evaluated.

\section{Materials and Methods}

\subsection{Methodological Assumptions}

A pot vegetation experiment was conducted in the greenhouse at the University of Warmia and Mazury, Olsztyn (north-east of Poland), in polyethylene pots, in four replications. The pots were filled with $2.8 \mathrm{~kg}$ of soil from the arable-humus soil horizon of Eutric Cambisol collected at the Teaching and Experimental Centre in Tomaszkowo (NE Poland, 53.7161 N, 20.4167 E), with the granulometric composition - according to the granulation classification developed by the United States Department of Agriculture-typical of loamy sand (sand $>0.05 \mathrm{~mm}, 78.08 \%$; silt $0.02-0.05 \mathrm{~mm}$, $20.46 \%$; and clay $<0.002 \mathrm{~mm}, 1.46 \%$ ). Basic physicochemical properties of the soil used in the experiment are provided in Table 1 . The experiment examined the effectiveness of sewage sludge at $0,4,8$ and $12 \mathrm{~g} / \mathrm{kg}$ of soil in alleviating the impact of contamination with diesel oil at $0,5,10$ and $15 \mathrm{~mL} / \mathrm{kg}$ d.m. of soil on plants. The diesel oil was purchased at an Orlen filling station. The diesel oil with a density of $845 \mathrm{~g} / \mathrm{L}$ contained polycyclic aromatic hydrocarbons-mainly 3-cyclic, but also 4- and 6-cyclic ones. The detailed characteristics of the diesel oil Verva-type B (DO) can be found at www.orlen.pl. The sewage sludge was obtained at the Wastewater Treatment Plant in Tyrowo (north-east of Poland). The chemical composition of the sewage sludge used in the experiment is given in Table 2 . Salmonella sp. and live eggs of intestinal parasites, i.e. Ascaris sp., Trichuris sp. and Toxocara sp., were not in sewage sludge. Nitrogen at $112 \mathrm{mg}\left[\mathrm{CO}\left(\mathrm{NH}_{2}\right)_{2}\right]$, phosphorus $39 \mathrm{mg}\left[\mathrm{KH}_{2} \mathrm{PO}_{4}\right]$, potassium $112 \mathrm{mg}$ $\left[\mathrm{KH}_{2} \mathrm{PO}_{4}+\mathrm{KCl}\right]$ and magnesium $15 \mathrm{mg} / \mathrm{kg}$ d.m. of soil 
Table 1 Physicochemical properties of soil used in the experiment

\begin{tabular}{lll}
\hline Physicochemical parameters & Unit & Content \\
\hline $\mathrm{pH}$ in $1 \mathrm{M} \mathrm{KCl} / \mathrm{L}$ & & 6.58 \\
Hydrolytic acidity (HA) & $\mathrm{mM}(+) / \mathrm{kg}$ & 8.50 \\
Total exchangeable bases (TEB) & $\mathrm{mM}(+) / \mathrm{kg}$ & 105.0 \\
Cation exchange capacity (CEC) & $\mathrm{mM}(+) / \mathrm{kg}$ & 113.5 \\
Base saturation (BS) & $\%$ & 92.5 \\
Total organic carbon (TOC) & $\mathrm{g} / \mathrm{kg} \mathrm{d} . \mathrm{m}$. & 12.7 \\
Total nitrogen & $\mathrm{g} / \mathrm{kg} \mathrm{d} . \mathrm{m}$. & 0.88 \\
Available phosphorus & $\mathrm{mg} / \mathrm{kg} \mathrm{d} . \mathrm{m}$. & 17.6 \\
Available potassium & $\mathrm{mg} / \mathrm{kg} \mathrm{d} . \mathrm{m}$. & 20.7 \\
Available magnesium & $\mathrm{mg} / \mathrm{kg} \mathrm{d} . \mathrm{m}$. & 8.8 \\
\hline
\end{tabular}

$\left[\mathrm{Mg} \mathrm{SO}_{4} \cdot 7 \mathrm{H}_{2} \mathrm{O}\right]$ were added to the soil in each pot. Oats (Avena sativa L.) of the Furman variety were used as the experimental plant. After the soil was mixed thoroughly with the diesel oil, sewage sludge and identical amounts of the mineral fertilizers, it was put into the pots and oats were sown at 12 plants per pot. The moisture content was maintained at $60 \%$ of the capillary water capacity during the plant growth. After 60 days of the plant growth, during the panicle emergence phase $(\mathrm{BBCH}$ 59), oats were harvested and samples of plant material were collected for laboratory analyses.

Table 2 Characteristics of sewage sludge used in the experiment

\begin{tabular}{lll}
\hline Properties & Unit & Content \\
\hline pH in 1 M KCl/L & & 8.2 \\
Dry matter & g/kg d.m. & 136.0 \\
Soil organic matter (SOM) & g/kg d.m. & 692.0 \\
Total nitrogen & g/kg d.m. & 51.0 \\
Total phosphorus & g/kg d.m. & 38.8 \\
Magnesium & g/kg d.m. & 8.9 \\
Calcium & g/kg d.m. & 39.8 \\
Cadmium & $\mathrm{mg} / \mathrm{kg} \mathrm{d} . \mathrm{m}$. & 1.10 \\
Lead & $\mathrm{mg} / \mathrm{kg} \mathrm{d} . \mathrm{m}$. & 17.2 \\
Chromium & $\mathrm{mg} / \mathrm{kg} \mathrm{d} . \mathrm{m}$. & 56.6 \\
Nickel & $\mathrm{mg} / \mathrm{kg} \mathrm{d} . \mathrm{m}$. & 28.5 \\
Zinc & $\mathrm{mg} / \mathrm{kg} \mathrm{d} . \mathrm{m}$. & 849.0 \\
Copper & $\mathrm{mg} / \mathrm{kg} \mathrm{d} . \mathrm{m}$. & 490.0 \\
Mercury & $\mathrm{mg} / \mathrm{kg} \mathrm{d} . \mathrm{m}$. & 0.24 \\
\hline
\end{tabular}

2.2 Methodology of the Laboratory and Statistical Analyses

The plant material was cut up, dried at $60{ }^{\circ} \mathrm{C}$ and ground. Subsequently, it was subjected to wet mineralization in 95\% sulphuric acid (analytical grade, density of $1.832 \mathrm{~g} / \mathrm{mL}$ ) and the following were determined: total nitrogen content by the Kjeldahl method (Bremner 1965), phosphorus content by the colorimetric method (Ostrowska et al. 1991), and potassium, calcium, magnesium and sodium content by the flame absorption atomic spectroscopy (Ostrowska et al. 1991). Before the experiment was set up, the granulometric composition of the soil was determined by the areometric method (PN-R-04032 1998), pH in $1 \mathrm{M} \mathrm{KCl/L}$ by the potentiometric method (ISO 10390 2005), hydrolytic acidity (HA) and the total exchangeable bases (TEB) by the Kappen method (Carter and Gregorich 2008), the content of total nitrogen by the Kjeldahl method (ISO 11261 1995), total organic carbon (TOC) by the Tiurin method (Nelson and Sommers 1996), available phosphorus and potassium by the Egner-Riehm method (Egner et al. 1960) and magnesium by the Schachtschabel method (Schlichting et al. 1995). The experiment results were analysed statistically by performing a two-way analysis of variance ANOVA and a principal component analysis (PCA) and by calculating the percent of observed variance with the $\eta 2$ coefficient by the ANOVA method with the Statistica package (Dell Inc. 2016).

\section{Results}

The application of increasing doses of diesel oil, as well as sewage sludge, had a significant impact on the content of the macroelements under study in the aboveground parts of oats.

Nitrogen Increasing doses of the diesel oil in the soil in which oats were grown reduced the total nitrogen content in the above-ground parts by $30 \%(r=-0.802)$ in the series with no sludge addition. The application of the sewage sludge resulted in an increase in the nitrogen content in the parts of oats under analysis. The nitrogen content was found to increase by $23 \%$ in the soil contaminated with the largest amount of diesel oil $(15 \mathrm{~mL} /$ $\mathrm{kg})$ and with the largest addition of sludge $(12 \mathrm{~g} / \mathrm{kg} \mathrm{d} . \mathrm{m}$. of soil) compared to the parallel pot in the series without 
sewage sludge addition. The statistical analysis revealed a highly significant negative correlation between increasing levels of soil contamination with diesel oil and the element content in the above-ground biomass of oats (Table 3 ).

Phosphorus Increasing levels of soil contamination with diesel oil in the series without addition of the sewage sludge increased the phosphorus content in the above-ground parts of oats by $38 \%(r=-0.806)$ (Table 3). A positive correlation between the analysed variables was also observed in the other experiment series. Adding sludge to the soil reduced this macroelement content by 7 to $13 \%$ compared to the series without sewage sludge addition. The application of sewage sludge at $12 \mathrm{~g} / \mathrm{kg} \mathrm{d}$.m. resulted in the largest reduction of phosphorus phytoavailability. It was a series with the lowest average element content in the above-ground parts of oats ( $3.212 \mathrm{~g} / \mathrm{kg} \mathrm{d.m}$.).

Potassium The potassium content in the above-ground parts of the plant under study was found to decrease with the level of contamination with diesel oil increasing to 10 and $15 \mathrm{~mL} / \mathrm{kg}$ d.m. of soil in all the experiment series except for one with an addition of the sewage sludge at $4 \mathrm{~g} / \mathrm{kg} \mathrm{d}$.m. of soil, in which its impact was less conclusive (Table 4). A highly negative correlation was demonstrated for the series without sludge addition $(r=-$ $0.829)$. A statistically significant reduction of the average potassium content in the above-ground parts of oats was observed when the soil was contaminated with diesel oil at $15 \mathrm{~mL} / \mathrm{kg} \mathrm{d.m}$. of soil. The addition of sewage sludge to the soil did not have a significant impact on the average element content in the oats' above-ground parts, regardless of its dose.

Sodium Increasing levels of soil contamination with diesel oil resulted in a significant reduction of the average sodium content in the above-ground parts of oats (Table 4). A highly significant negative correlation between the variables under analysis was demonstrated in all the experiment series. The strongest impact of soil contamination with diesel oil on the sodium content in the above-grounds parts of oats (reduction by $32 \%, \mathrm{r}=$ -0.936 ) in the series with no sludge addition was observed in the soil with the highest contamination level$15 \mathrm{~mL} / \mathrm{kg}$ d.m. of soil. Soil remediation with sludge resulted in a significant increase in the macroelement

Table 3 Content of total-N and phosphorus in above-ground parts of oat (Avena sativa L.) in $\mathrm{g} / \mathrm{kg}$ d.m

\begin{tabular}{|c|c|c|c|c|c|}
\hline \multirow[t]{2}{*}{ Diesel oil dose in $\mathrm{w} \mathrm{mL} / \mathrm{kg} \mathrm{d.m.} \mathrm{of} \mathrm{soil}$} & \multicolumn{4}{|c|}{ Sewage sludge dose in $\mathrm{g} / \mathrm{kg} \mathrm{d.m}$. of soil } & \multirow[t]{2}{*}{ Average } \\
\hline & 0 & 4 & 8 & 12 & \\
\hline \multicolumn{6}{|l|}{ Total-N } \\
\hline 0 & $10.36^{\mathrm{c}}$ & $11.34^{\mathrm{b}}$ & $11.62^{\mathrm{b}}$ & $13.86^{\mathrm{a}}$ & 11.80 \\
\hline 5 & $7.56^{\mathrm{ef}}$ & $7.84^{\mathrm{ef}}$ & $10.22^{\mathrm{c}}$ & $11.90^{\mathrm{b}}$ & 9.38 \\
\hline 10 & $8.12^{\mathrm{e}}$ & $7.70^{\mathrm{ef}}$ & $8.96^{\mathrm{d}}$ & $10.08^{\mathrm{c}}$ & 8.72 \\
\hline 15 & $7.28^{\mathrm{f}}$ & $7.70^{\mathrm{ef}}$ & $9.80^{\mathrm{c}}$ & $8.96^{\mathrm{d}}$ & 8.44 \\
\hline Average & 8.33 & 8.65 & 10.15 & 11.20 & 9.58 \\
\hline $\mathrm{r}$ & $-0.802^{* *}$ & $-0.794^{* *}$ & $-0.781^{* *}$ & $-0.993^{* *}$ & $-0.908^{* *}$ \\
\hline \multicolumn{6}{|c|}{ LSD for diesel oil dose, $0.172^{* *}$; sewage sludge dose, $0.172^{* *}$; interaction, $0.344^{* *}$} \\
\hline \multicolumn{6}{|l|}{ Phosphorus } \\
\hline 0 & $3.366^{\mathrm{ef}}$ & $3.448^{\text {cde }}$ & $3.140^{\text {gh }}$ & $3.156^{\mathrm{fgh}}$ & 3.278 \\
\hline 5 & $3.372^{\mathrm{ef}}$ & $3.358^{\mathrm{efg}}$ & $3.666^{\mathrm{bc}}$ & $3.367^{\mathrm{ef}}$ & 3.441 \\
\hline 10 & $3.445^{\mathrm{de}}$ & $3.661^{\text {bcd }}$ & $3.035^{\mathrm{h}}$ & $3.000^{\mathrm{h}}$ & 3.285 \\
\hline 15 & $4.652^{\mathrm{a}}$ & $3.396^{\mathrm{e}}$ & $3.750^{\mathrm{b}}$ & $3.323^{\mathrm{efg}}$ & 3.780 \\
\hline Average & 3.709 & 3.466 & 3.398 & 3.212 & 3.446 \\
\hline $\mathrm{r}$ & $0.806^{* *}$ & 0.140 & 0.427 & 0.103 & $0.742^{* *}$ \\
\hline
\end{tabular}

Significant at $* * p \leq 0.01 ; * p \leq 0.05 ; r$ correlation coefficient

$a, b, c, d, e, f, g, h$-average values denoted by the different letters are significantly different (Anova, Tukey's HSD test) 
Table 4 Content of potassium and sodium in above-ground parts of oat (Avena sativa L.) in $\mathrm{g} / \mathrm{kg} \mathrm{d.m}$

\begin{tabular}{|c|c|c|c|c|c|}
\hline \multirow[t]{2}{*}{ Diesel oil dose in $\mathrm{w} \mathrm{mL} / \mathrm{kg}$ d.m. of soil } & \multicolumn{4}{|c|}{ Sewage sludge dose in $\mathrm{g} / \mathrm{kg}$ d.m. of soil } & \multirow[t]{2}{*}{ Average } \\
\hline & 0 & 4 & 8 & 12 & \\
\hline \multicolumn{6}{|l|}{ Potassium } \\
\hline 0 & $21.56^{\mathrm{a}}$ & $20.76^{\mathrm{ab}}$ & $18.01^{\mathrm{gh}}$ & $18.56^{\mathrm{fgh}}$ & 19.72 \\
\hline 5 & $19.37^{\text {cdef }}$ & $18.18^{\mathrm{fgh}}$ & $19.99^{\mathrm{bcd}}$ & $19.89^{\text {bcde }}$ & 19.36 \\
\hline 10 & $20.44^{\mathrm{abc}}$ & $19.23^{\text {cdefg }}$ & $18.86^{\text {defgh }}$ & $18.63^{\mathrm{efgh}}$ & 19.29 \\
\hline 15 & $17.58^{\mathrm{h}}$ & $17.97^{\mathrm{gh}}$ & $18.65^{\mathrm{efgh}}$ & $17.65^{\mathrm{h}}$ & 17.96 \\
\hline Average & 19.74 & 19.04 & 18.88 & 18.68 & 19.08 \\
\hline $\mathrm{r}$ & $-0.829^{* *}$ & $-0.741^{*}$ & 0.124 & $-0.560^{* *}$ & $-0.896^{* *}$ \\
\hline \multicolumn{6}{|c|}{ LSD for diesel oil dose, $0.355^{* *}$; sewage sludge dose, $0.355^{* *}$; interaction, $0.748^{* *}$} \\
\hline \multicolumn{6}{|l|}{ Sodium } \\
\hline 0 & $1.218^{\mathrm{de}}$ & $1.485^{\mathrm{c}}$ & $1.857^{\mathrm{b}}$ & $2.311^{\mathrm{a}}$ & 1.720 \\
\hline 5 & $0.961^{\mathrm{f}}$ & $1.170^{\mathrm{de}}$ & $1.283^{\mathrm{d}}$ & $1.210^{\mathrm{de}}$ & 1.156 \\
\hline 10 & $0.906^{\mathrm{fg}}$ & $0.919^{\mathrm{fg}}$ & $0.892^{\mathrm{fg}}$ & $1.136^{\mathrm{e}}$ & 0.963 \\
\hline 15 & $0.829^{\mathrm{g}}$ & $0.849^{\mathrm{fg}}$ & $0.872^{\mathrm{fg}}$ & $0.975^{\mathrm{f}}$ & 0.881 \\
\hline Average & 0.979 & 1.106 & 1.226 & 1.408 & 1.180 \\
\hline $\mathrm{r}$ & $-0.936^{* * *}$ & $-0.968^{* *}$ & $-0.936^{* *}$ & $-0.864^{* *}$ & $-0.926^{\text {*** }}$ \\
\hline
\end{tabular}

Significant at $* * p \leq 0.01 ; * p \leq 0.05 ; r$ correlation coefficient

$a, b, c, d, e, f, g, h$-average values denoted by the different letters are significantly different (Anova, Tukey's HSD test)

content in the above-ground biomass of oats. A $44 \%$ sodium content increase compared to the control object (without sewage sludge addition) was observed in the series with the largest amount of sludge.

Calcium The lowest calcium content in the above-ground parts of oats was found in pots with soil contaminated with $10 \mathrm{~mL}$ of diesel oil per $1 \mathrm{~kg} \mathrm{d.m}$. of soil (Table 5). Its highest dose $(15 \mathrm{~mL} / \mathrm{kg}$ d.m. of soil) increased the macroelement content in the plants. The increasing soil contamination level in the control series increased the calcium content in the above-ground parts of oats by $34 \%(r=0.790)$. A negative correlation between the variables under analysis was observed in the series with sewage sludge (8 and $12 \mathrm{~g} / \mathrm{kg}$ d.m. of soil), with highly significant correlations particularly observed in pots with the largest addition of sewage sludge.

Magnesium A negative correlation between the soil contamination with diesel oil and magnesium content in the above-ground biomass of oats was observed in all experiment series (Table 5). The greatest reduction in magnesium content (by 35\%, $r=-0.925$ ) in the aboveground parts of oats was observed in pots containing soil contaminated with $15 \mathrm{~mL}$ of diesel oil per $1 \mathrm{~kg}$ of soil, with an addition of sewage sludge at $12 \mathrm{~g} / \mathrm{kg}$ d.m. of soil. An increasing amount of sewage sludge added to the soil significantly increased the content of the macroelement under study in the above-ground parts of oats. It was $19 \%$ on average in the series with the largest amount of sewage sludge compared to the pots without it.

PCA and Correlation Coefficients The correlation coefficients (Table 6) and the PCA results (Fig. 1) confirmed the presence of significant correlations between the macroelements in the above-ground parts of oats. The principal component analysis revealed changes in the macroelement content in the above-ground parts of oats caused by the contamination with diesel oil and the addition of sewage sludge (Fig. 1). The first group of macroelements, i.e. nitrogen, sodium and magnesium, accounted for $50.67 \%$ of the information on the chemical composition of oats in the input data, whereas the other group, comprising calcium, phosphorus and potassium, accounted for $26.72 \%$. The macroelement vectors were of a similar length, except for potassium and phosphorus, whose vectors were shorter than the others. Therefore, the 
Table 5 Content of calcium and magnesium in above-ground parts of oat (Avena sativa L.) in $\mathrm{g} / \mathrm{kg} \mathrm{d.m}$

\begin{tabular}{|c|c|c|c|c|c|}
\hline \multirow[t]{2}{*}{ Diesel oil dose in $\mathrm{w} \mathrm{mL} / \mathrm{kg}$ d.m. of soil } & \multicolumn{4}{|c|}{ Sewage sludge dose in $\mathrm{g} / \mathrm{kg}$ d.m. of soil } & \multirow[t]{2}{*}{ Average } \\
\hline & 0 & 4 & 8 & 12 & \\
\hline \multicolumn{6}{|l|}{ Calcium } \\
\hline 0 & $6.241^{\mathrm{efg}}$ & $7.117^{\mathrm{bc}}$ & $6.758^{\text {bcde }}$ & $8.053^{\mathrm{a}}$ & 7.042 \\
\hline 5 & $6.617^{\text {bcdef }}$ & $6.471^{\text {defg }}$ & $6.152^{\mathrm{fg}}$ & $6.573^{\text {cdefg }}$ & 6.453 \\
\hline 10 & $6.339^{\mathrm{efg}}$ & $6.050^{\mathrm{g}}$ & $5.354^{\mathrm{h}}$ & $6.950^{\mathrm{bcd}}$ & 6.173 \\
\hline 15 & $8.336^{\mathrm{a}}$ & $7.153^{\mathrm{b}}$ & $6.549^{\text {defg }}$ & $6.330^{\mathrm{efg}}$ & 7.092 \\
\hline Average & 6.883 & 6.698 & 6.203 & 6.977 & 6.690 \\
\hline $\mathrm{r}$ & $0.790^{* *}$ & -0.076 & -0.297 & $-0.812^{* *}$ & -0.037 \\
\hline \multicolumn{6}{|c|}{ LSD for diesel oil dose, $0.153^{* *}$; sewage sludge dose, $0.153^{* *}$; interaction, $0.307^{* *}$} \\
\hline \multicolumn{6}{|l|}{ Magnesium } \\
\hline 0 & $1.986^{\mathrm{b}}$ & $1.953^{b c}$ & $2.008^{b}$ & $2.367^{\mathrm{a}}$ & 2.078 \\
\hline 5 & $1.350^{\mathrm{i}}$ & $1.338^{\mathrm{i}}$ & $1.701^{\mathrm{ef}}$ & $1.823^{\mathrm{de}}$ & 1.553 \\
\hline 10 & $1.344^{\mathrm{i}}$ & $1.554^{\mathrm{gh}}$ & $1.428^{\mathrm{hi}}$ & $1.837^{\mathrm{cd}}$ & 1.541 \\
\hline 15 & $1.686^{\mathrm{f}}$ & $1.554^{\mathrm{gh}}$ & $1.636^{\mathrm{fg}}$ & $1.530^{\mathrm{gh}}$ & 1.602 \\
\hline Average & 1.592 & 1.600 & 1.693 & 1.889 & 1.694 \\
\hline $\mathrm{r}$ & -0.380 & -0.494 & $-0.747^{*}$ & $-0.925^{* *}$ & $-0.722^{* *}$ \\
\hline
\end{tabular}

Significant at $* * p \leq 0.01 ; * p \leq 0.05 ; r$ correlation coefficient

$a, b, c, d, e, f, g, h, i$-average values denoted by the different letters are significantly different (Anova, Tukey's HSD test)

contribution of these two components to the data set correlation was the smallest. The strongest positive correlations were observed between sodium and nitrogen, magnesium, and between magnesium and nitrogen, whereas the strongest negative correlation was observed between nitrogen and phosphorus, and slightly weaker between sodium and phosphorus. The dispersion of points in Fig. 2 shows that an addition of sewage sludge usually had a positive effect on the elements under analysis in the above-ground parts of oats.

Percent of Variation Determination of the percent of the variation as $\eta 2$ with the ANOVA method showed that the content of macroelements in oats depended to the greatest extent on the diesel oil dose, especially in the case of nitrogen, magnesium and sodium with 50.86 , 62.99 and $68.20 \%$ shares of a variable, respectively (Fig. 3). Much lower values were demonstrated for the other elements. They lay within the range from $28.91 \%$ for calcium to $31.54 \%$ for potassium. Its contribution was much smaller in the samples of the above-ground parts of oats collected from the pots to which sewage sludge was added and ranged from $11.27 \%$ (potassium) to $22.18 \%$ (phosphorus). The only exception was the content of nitrogen in oats, for which the variable was $39.10 \%$.

Table 6 Correlation coefficients $(r)$ between content of macroelements in above-ground parts of oat (Avena sativa L.)

\begin{tabular}{|c|c|c|c|c|c|}
\hline Macroelements & $\mathrm{P}$ & K & $\mathrm{Na}$ & $\mathrm{Ca}$ & $\mathrm{Mg}$ \\
\hline $\mathrm{N}$ & $-0.404^{* *}$ & 0.217 & $0.841^{* *}$ & 0.202 & $0.856^{* *}$ \\
\hline $\mathrm{P}$ & & -0.127 & $-0.379^{* *}$ & $0.407^{* *}$ & -0.156 \\
\hline $\mathrm{K}$ & & & 0.044 & $-0.302^{*}$ & 0.148 \\
\hline $\mathrm{Na}$ & & & & $0.374^{*}$ & $0.820^{* * *}$ \\
\hline $\mathrm{Ca}$ & & & & & $0.506^{* *}$ \\
\hline
\end{tabular}

Significant at $* * p \leq 0.01 ; * p \leq 0.05$ 
Fig. 1 Content of macroelements in the above-ground parts of oats (Avena sativa L.) illustrated with the PCA method. Key: vectors represent analysed variable (content of $\mathrm{N}, \mathrm{P}, \mathrm{K}, \mathrm{Na}, \mathrm{Ca}$ and $\mathrm{Mg}$ )

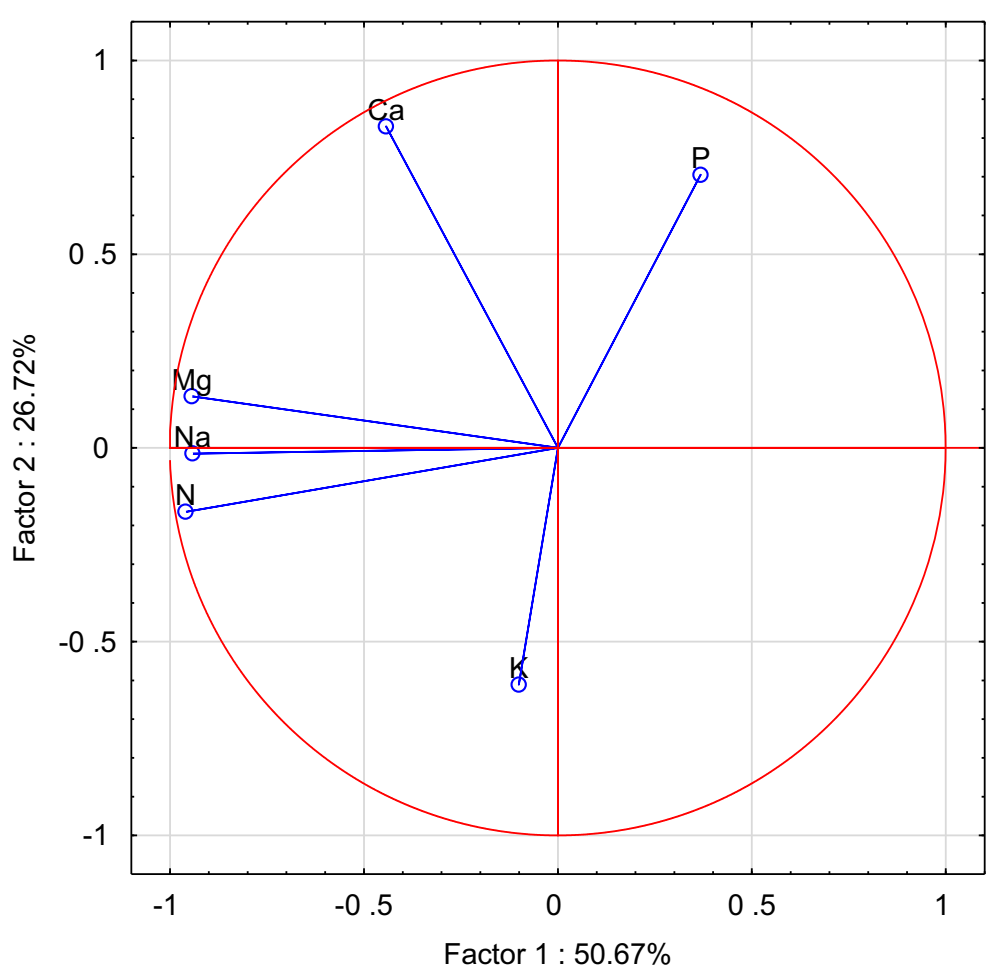

\section{Discussion}

Progressive industrialization and the development of the automotive industry are among the main causes of environmental pollution with petroleum products. Accumulation of petroleum products in soil negatively affects on the condition of ecosystems (Tang et al. 2011). Areas contaminated with petroleum substances constitute as much as $45 \%$ of all contaminated habitats in Europe (Masy et al. 2016). These compounds have a threat to living organisms, soil microorganisms and the functions of the ecosystem in contaminated areas (Ogboghodo
Fig. 2 Effect of amendments on content of macroelements in the above-ground parts of oats (Avena sativa L.) illustrated with the PCA method. Key: points show the samples with elements ( $S 0$ without sewage sludge, SI 4 g, SII 8 g, SIII $12 \mathrm{~g}$ sewage sludge per $\mathrm{kg}$ of soil; 0-0 g, 1-5 g, 2-10 g, 3-15 g diesel oil per $\mathrm{kg}$ of soil)

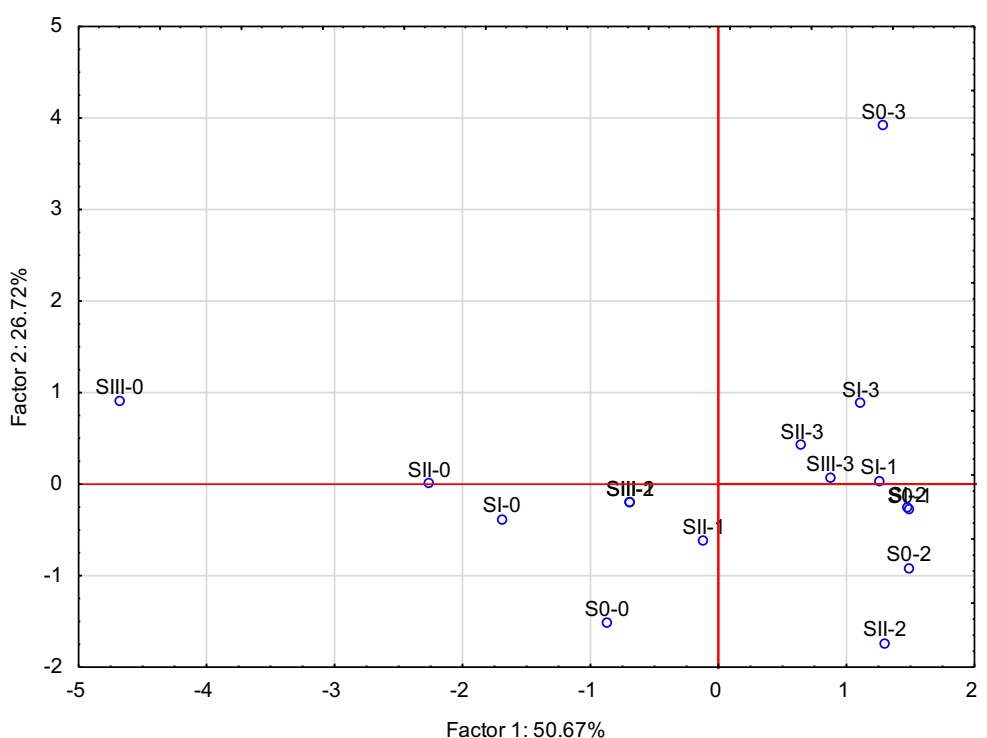


Fig. 3 Percent contribution of variable factors according to the content of macroelements in above-ground parts of oat (Avena sativa L.). DO diesel oil dose, SS sewage sludge dose, $\mathrm{DO} \cdot \mathrm{SS}$ diesel oil dose and sewage sludge dose interaction

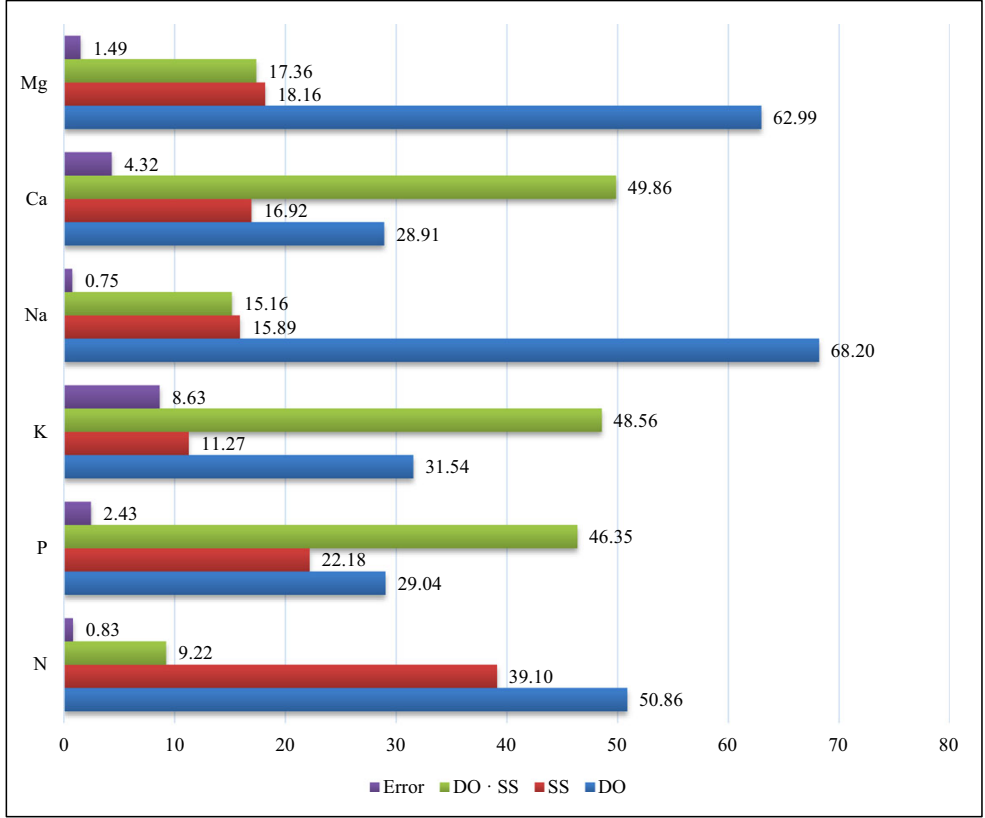

et al. 2004; Souza et al. 2014). The degrading effect of petroleum derivatives on soil causes a reduction in biodiversity, bioavailable forms of nitrogen and phosphorus and other elements and a violation of water and oxygen conditions (Obire and Nwabueta 2002; Souza et al. 2014). Soaking the soil with oil derivatives can also affect on the uptake of particular nutrients by plants and their content in their organs (Wyszkowski et al. 2004; Wang et al. 2017), significantly reducing the uptake of macroelements (Borowik and Wyszkowska 2018).

Wyszkowski and Ziółkowska (2009) demonstrated that diesel oil and petrol contribute to the reduction of nitrogen content in plants, which is consistent with the results of this experiment. A decrease in nitrogen content (over twofold) and a slight increase in the phosphorus content in the above-ground parts of oats under the influence of soil oil contamination with diesel oil was also noted (Wyszkowski and Wyszkowska 2005). The probable reason for the reduction of nitrogen content in plant organs on soil contaminated with petroleum derivatives is the increase in the population of soil microorganisms. The soil microorganisms constitute the main source of carbon and energy (John et al. 2010). Under these conditions, they absorb significant amounts of macroelements, mainly nitrogen. Consequently, the availability of this element for plants is reduced (Margesin and Schinner 1997). In soils pressured by petroleum compounds, as a result of violation of oxygen conditions, the development of denitrification bacteria is intensified, with simultaneous inhibition or reduction of nitrifying bacteria activity (John et al. 2010; Kucharski et al. 2010). This phenomenon leads to nitrogen losses in soil (John et al. 2010) and thus to the deficit of available forms of this element for plants, which may also reduce its content in plant organs.

Gospodarek et al. (2019) evaluated the long-term effect of soil contamination with petroleum products at $6 \mathrm{~g} / \mathrm{kg} \mathrm{d.m}$. of soil on the yield and chemical composition of winter wheat. Four years after the contamination, no significant effect was observed of the diesel oil on the nitrogen, magnesium or calcium content in the leaves of the plant under study. Meanwhile, the content of sulphur and heavy metals, such as manganese, copper and zinc, was found to decrease. They did not observe any effect of petroleum products on winter wheat growth and yield, which showed the crop's high resistance to such contamination. Houshmandfar and Asli (2011) demonstrated the toxic effect of a mixture of diesel oil and petrol in the total amount of $20 \mathrm{~mL} / \mathrm{kg}$ of soil on seed germination and the growth of wheat, barley, alfalfa and clover. Long-chain alkanes and aromatic compounds are the strongest plant growth inhibitors among petroleum products (Inckot et al. 2011; Olson et al. 2007).

The content of sodium, magnesium and partly calcium as determined in the above-ground parts of oats in 
this study was found to decrease following soil contamination with diesel oil at all of the doses applied. The largest dose (15 mL/kg d.m. of soil) also decreased the potassium content (statistically significantly). Similar findings were found by Wyszkowski and Wyszkowska (2005), who showed that diesel oil at a dose of $6 \mathrm{~g} / \mathrm{kg}$ d.m. of soil causes an increase in the potassium content in plants, but at higher doses it strongly reduces the content of this macroelement. A decrease in the potassium content in leaves and stalks of broad bean was also confirmed by Rusin et al. (2017) following the application of 9 and $18 \mathrm{~g}$ of diesel oil per $1 \mathrm{~kg}$ of soil. The authors also found magnesium accumulation in the plant parts under analysis increased in these conditions.

Sewage sludge is rich in inorganic nutrients and organic matter, which makes it usable as organic fertilizer, as well as to restore the arable soil layer in the reclamation process (Janowska et al. 2017). There are many positive aspects of the use of sewage sludge. Their application to soil increases the content of nutrients (mainly nitrogen, phosphorus and potassium, as well as their bioavailable forms) and organic matter in soil, improving the balance of humus compounds (Suhadolc et al. 2010). In addition, the application of sewage sludge improves the soil structure and porosity (Kominko et al. 2019) and its physicochemical and enzymatic properties (Angin and Yaganoglu 2011; Siebielec et al. 2018). Organic and mineral compounds introduced together with sewage sludge to soil have a significant impact on the structure of soil microorganisms (bacteria and fungi), increasing their number and metabolic activity (Sullivan et al. 2005; Suhadolc et al. 2010). Urbaniak et al. (2017) demonstrated that treating soil with sewage sludge at 3 and $9 \mathrm{t} / \mathrm{ha}$ resulted in a gradual increase in the humus fraction content, total organic carbon and bacteria count. Hur and Park (2003) assessed the effect of an addition of sewage sludge on the recultivation of soil contaminated with diesel oil. After 30 days, the highest level of petroleumderived hydrocarbons $(98.1 \%)$ was reported for the system with a soil to fresh weight of sludge ratio of 1:0.5.

Sewage sludge applied in this study at $12 \mathrm{~g} / \mathrm{kg}$ d.m. of soil significantly increased the content of nitrogen, sodium and magnesium in the above-ground parts of oats in all the pots. On the other hand, it had the opposite effect in the case of potassium, and especially phosphorus, where it reduced significantly the content of these elements in the above-ground parts of oats. No significant effect was observed for calcium, with smaller doses of the neutralizing substances resulting in a decrease in the macroelement content in oats. Similar results were produced in a study by Antonkiewicz et al. (2020), who analysed the impact of communal sewage sludge and bottom ash on the chemical composition of a mixture of grasses and leguminous plants. It was found that plants exposed to sewage sludge at $5 \mathrm{~kg} /$ $\mathrm{m}^{2}$ contained the highest levels of nitrogen, phosphorus and sodium. This also affected magnesium accumulation and significantly reduced the calcium content compared to the control object. In contrast, they found that the potassium content was unchanged. Low calcium content in plant biomass may be associated with high organic matter capacity of sewage sludge (Antonkiewicz et al. 2020). Under conditions of almost neutral soil $\mathrm{pH}$, stable organic complexes with calcium may be formed. Calcium becomes less bioavailable and its uptake by plant roots is limited (Nunes et al. 2009). Boudjabi et al. (2019) concluded that sewage sludge can alleviate the effects of environmental stress while improving wheat growth and yield of wheat.

The study findings indicate that the sewage sludge used in the remediation process not only had a positive impact on the nutrient availability, but it also reduced the adverse impact of high diesel oil doses on the growth and chemical composition of the plant under study.

\section{Conclusion}

The macroelement content in the above-ground parts of oats depended on the soil contamination with diesel oil and on the addition of sewage sludge to the soil. Soil contamination with diesel oil produced significant changes in the content of all macroelements under study in the above-ground biomass of oats. Increasing doses of the petroleum product in the series without sludge addition caused a decrease the nitrogen, potassium, sodium and magnesium contents in the above-ground parts of oats. A positive correlation was observed for the content of phosphorus and calcium. The addition of sewage sludge to the soil alleviated the negative impact of diesel oil on the chemical composition of the plants under study. Compared to the series without sewage sludge addition, this resulted in an increase in the average content of nitrogen, sodium and magnesium (as opposed to phosphorus and partly calcium) in the above-ground parts of oats. 
Funding The project was financed by the University of Warmia and Mazury in Olsztyn (Poland) as part of the topic No. 20.610.003-110. The project is financially supported by the Minister of Science and Higher Education in the range of the program entitled "Regional Initiative of Excellence" for the years 20192022, Project No. 010/RID/2018/19, amount of funding 12.000.000 PLN. The funders had no role in the design of the study; in the collection, analyses, or interpretation of data; in the writing of the manuscript; or in the decision to publish the results.

Open Access This article is licensed under a Creative Commons Attribution 4.0 International License, which permits use, sharing, adaptation, distribution and reproduction in any medium or format, as long as you give appropriate credit to the original author(s) and the source, provide a link to the Creative Commons licence, and indicate if changes were made. The images or other third party material in this article are included in the article's Creative Commons licence, unless indicated otherwise in a credit line to the material. If material is not included in the article's Creative Commons licence and your intended use is not permitted by statutory regulation or exceeds the permitted use, you will need to obtain permission directly from the copyright holder. To view a copy of this licence, visit http://creativecommons.org/licenses/by/4.0/.

\section{References}

Abdel-Shafy, H. I., \& Mansour, M. S. M. (2016). A review on polycyclic aromatic hydrocarbons: Source, environmental impact, effect on human health and remediation. Egyptian Journal of Petroleum, 25(1), 107-123.

Adam, G., Gamoh, K., Morris, D. G., \& Duncan, H. (2002). Effect of alcohol addition on the movement of petroleum hydrocarbon fuels in soil. Science of the Total Environment, 286(1/3), $15-25$.

Agbogidi, O. M., \& Eshegbeyi, O. F. (2006). Performance of Dacryodes edulis (Don. G. Lam H. J.) seeds and seedlings in a crude oil contaminated soil. Journal of Sustainable Forestry, 22(3-4), 1-13.

Angin, I., \& Yaganoglu, A. V. (2011). Effects of sewage sludge application on some physical and chemical properties of a soil affected by wind erosion. Journal of Agricultural Science and Technology, 13, 757-768.

Antonkiewicz, J., Popławska, A., Kołodziej, B., Ciarkowska, K., Gambuś, F., Bryk, M., \& Babula, J. (2020). Application of ash and municipal sewage sludge as macronutrient sources in sustainable plant biomass production. Journal of Environmental Management, 264, 110450.

Bona, C., de Rezende, I. M., de Oliveira Santos, G., \& de Souza, L. A. (2011). Effect of soil contaminated by diesel oil on the germination of seeds and the growth of Schinus terebinthifolius Raddi (Anacardiaceae) seedlings. Brazilian Archives of Biology and Technology, 54(6), 1379-1387.

Borowik, A., \& Wyszkowska, J. (2018). Response of Avena sativa L. and the soil microbiota to the contamination of soil with Shell diesel oil. Plant, Soil and Environment, 64(3), 102107.
Boudjabi, S., Kribaa, M., \& Chenchouni, H. (2019). Sewage sludge fertilization alleviates drought stress and improves physiological adaptation and yield performances in durum wheat (Triticum durum): A double-edged sword. Journal of King Saud University - Science, 31, 336-344.

Bremner, J. M. (1965). Total nitrogen. In C. A. Black et al. (Eds.), Methods of soil analysis, part 2. Chemical and microbiological properties (Agronomy 9). Madison: American Society of Agronomy 1149-1178 p.

Carter, M. R., \& Gregorich, E. G. (Eds.). (2008). Soil sampling and methods of analysis (2nd ed.1224 p). Boca Raton, FL, USA: CRC Press.

Cheng, Y., \& Nathanail, P. C. (2009). Generic assessment criteria for human health risk assessment of potentially contaminated land in China. Science of the Total Environment, 408(2), 324-339.

Clark, C. J. I. I. (2003). Field detector evaluation of organic clay soils contaminated with diesel fuel. Environmental Forensics, 4(3), 167-173.

Dell, Inc., (2016). Dell Statistica (data analysis software system), version 13. software.dell.com. Accessed 24 June 2020

Egner, H., Riehm, H., \& Domingo, W. R. (1960). Untersuchungen über die chemische Bodenanalyse als Grundlage für die Beurteilung des Nährstoffzustandes der Böden. II. Chemische Extractionsmethoden zur Phospor- und Kaliumbestimmung. Annals of the Royal Agricultural College of Sweden, 26, 199-215.

Gospodarek, J., Rusin, M., \& Nadgórska-Socha, A. (2019). Effect of petroleum-derived substances and their bioremediation on Triticum aestivum L. growth and chemical composition. Polish Journal of Environmental Studies, 28(4), 2131-2137.

Gray, M. R., Banerjee, D. K., Fedorak, P. M., Hashimoto, A., Masliyah, J. H., \& Pickard, M. A. (1994). Biological remediation of anthracene-contaminated soil in rotating bioreactors. Applied Microbiology and Biotechnology, 40, 93.

Houshmandfar, A., \& Asli, D. E. (2011). Seed germination and seedling growth of wheat, barley, alfalfa and clover as affected by gasoline and diesel fuel mixture. Advances in Environmental Biology, 5(6), 1250-1255.

Hunt, L. J., Duca, D., Dan, T., \& Knopper, L. D. (2019). Petroleum hydrocarbon (PHC) uptake in plants: A literature review. Environmental Pollution, 245, 472-484.

Hur, J. M., \& Park, J. A. (2003). Effect of sewage sludge mix ratio on the biodegradation of diesel-oil in a contaminated soil composting. Korean Journal of Chemical Engineering, 20(2), 307-314.

Hussain, I., Puschenreiter, M., Gerhard, S., Sani, S. G. A. S., Khan, W. U., \& Reichenauer, T. G. (2019). Differentiation between physical and chemical effects of oil presence in freshly spiked soil during rhizoremediation trial. Environmental Science and Pollution Research, 26(18), 18451-18464.

Inckot, R. C., de Oliveira Santos, G., de Souza, L. A., \& Bona, C. (2011). Germination and development of Mimosa pilulifera in petroleum-contaminated soil and bioremediated soil. Flora - Morphology Distribution Functional Ecology of Plants, 206(3), 261-266.

ISO 10390. (2005). Soil quality - determination of $p H$. Geneva, Switzerland: International Organization for Standardization. 
ISO 11261. (1995). Soil quality-determination of total nitrogen-modified Kjeldahl method. Geneva, Switzerland: International Organization for Standardization.

Jain, P. K., Gupta, V. K., Gaur, R. K., Lowry, M., Jaroli, D. P., \& Chauhan, U. K. (2011). Bioremediation of petroleum oil contaminated soil and water. Research Journal of Environmental Toxicology, 5, 1-26.

Janowska, B., Szymański, K., Sidełko, R., Siebielska, I., \& Walendzik, B. (2017). Assessment of mobility and bioavailability of mercury compounds in sewage sludge and composts. Environmental Research, 156, 394-403.

John, R. C., Akpan, M. M., Essien, J. P., \& Ikpe, D. I. (2010). Impact of crude oil pollution on the densities of nitrifying and denitrifying bacteria in the rhizosphere of tropical legumes grown on wetland soil. Nigerian Journal of Microbiology, 24(1), 2088-2094.

Khalilova, H. K. (2015). The impact of oil contamination on soil ecosystem. Biological and Chemical Research, 2015, 133139.

Kominko, H., Gorazda, K., Wzorek, Z., \& Wojtas, K. (2018). Sustainable management of sewage sludge for the production of organo-mineral fertilizers. Waste and Biomass Valorization, 9, 1817-1826.

Kominko, H., Gorazda, K., \& Wzorek, Z. (2019). Potentiality of sewage sludge-based organo-mineral fertilizer production in Poland considering nutrient value, heavy metal content and phytotoxicity for rapeseed crops. Journal of Environmental Management, 248, 109283.

Kucharski, J., Tomkiel, M., Boros, E., \& Wyszkowska, J. (2010). The effect of soil contamination with diesel oil and petrol on the nitrification process. Journal of Elementology, 15(1), 111-118.

Margesin, R., \& Schinner, R. (1997). Laboratory bioremediation experiments with soil from a diesel-oil contaminated sitesignificant role of cold-adapted microorganisms and fertilizers. Journal of Chemical Technology and Biotechnology, 70, 92-98.

Masy, T., Demanèche, S., Tromme, O., Thonart, P., Jacques, P., Hilgsmann, S., \& Vogel, T. M. (2016). Hydrocarbon biostimulation and bioaugmentation in organic carbon and clayrich soils. Soil Biology and Biochemistry, 99, 66-74.

Moreno-Penaranda, R., Lloret, F., \& Alcaniz, J. M. (2004). Effects of sewage sludge on plant community composition in restored limestone quarries. Restoration Ecology, 12(2), 290296.

Nelson, D. W., \& Sommers, L. E. (1996). Total carbon, organic carbon, and organic matter. In D. L. Sparks (Ed.), Method of soil analysis: Chemical methods (pp. 1201-1229). American Society of Agronomy: Madison.

Nunes, F. C., Miyazawa, M., \& Pavan, M. A. (2009). Organic acid effect on calcium uptake by the wheat roots. Brazilian Archives of Biology and Technology, 52, 11-15.

Obire, O., \& Nwabueta, O. (2002). Effects of refined petroleum hydrocarbon on soil physico-chemical and bacteriological characteristics. Journal of Applied Structural Equation Modeling, 6(1), 39-44.

Ogboghodo, I. A., Iruaga, E. K., Osemwota, I. O., \& Chokor, J. U. (2004). An assessment of the effect of crude oil pollution on soil properties, germination and growth of maize (Zea mays) using two crude types - Forcados light and Escravos light. Environmental Monitoring and Assessment, 96(1-3), 143152.

Olson, P. E., Castro, A., Joern, M., DuTeau, N. M., Pilon-Smits, E. A. H., \& Reardon, K. F. (2007). Comparison of plant families in a greenhouse phytoremediation study on an aged polycyclic aromatic hydrocarbon-contaminated soil. Journal of Environmental Quality, 36, 1461.

Ostrowska, A., Gawliński, S., \& Szczubiałka, Z. (1991). Methods for analysis and evaluation of soil and plant properties. Warszawa: IOŚ 1-334 p. (in Polish).

PN-R-04032 (1998). Soil and mineral materials-sampling and determination of particle size distribution (pp 1-12). Warsaw: Polish Committee for Standardization.

Rusin, M., Gospodarek, J., \& Nadgórska-Socha, A. (2015). The effect of petroleum-derived substances on the growth and chemical composition of Vicia faba L. Polish Journal of Environmental Studies, 24(5), 2157-2166.

Rusin, M., Gospodarek, J., Nadgórska-Socha, A., \& Barczyk, G. (2017). Effect of petroleum-derived substances on life history traits of black bean aphid (Aphis fabae Scop.) and on the growth and chemical composition of broad bean. Ecotoxicology, 26, 308-319.

Schlichting, E., Blume, H. P., \& Stahr, K. (1995). Bodenkundliches Praktikum. Pareys Studientexte 81. Berlin: Blackwell Wissenschafts-Verlag 81 p.

Siebielec, G., Siebielec, S., \& Lipski, D. (2018). Long-term impact of sewage sludge, digestate and mineral fertilizers on plant yield and soil biological activity. Journal of Cleaner Production, 187, 372-379.

Sousa, A., Pereira, R., Antunes, S. C., Cachada, A., Pereira, E., Duarte, A. C., \& Gonçalves, F. (2008). Validation of avoidance assays for the screening assessment of soils under different anthropogenic disturbances. Ecotoxicology and Environmental Safety, 71, 661-670.

Souza, E. C., Vessoni-Penna, T. C., \& De Souza Olieira, R. P. (2014). Biosurfactant-enhanced hydrocarbon bioremediation: An overview. International Biodeterioration and Biodegradation, 89, 88-94.

Suhadolc, M., Schroll, R., Hagn, A., Dörfler, U., Schloter, M., \& Lobnik, F. (2010). Single application of sewage sludge impact on the quality of an alluvial agricultural soil. Chemosphere, 81, 1536-1543.

Sullivan, T. S., Stromberger, M. E., Paschke, M. W., \& Ippolito, J. A. (2005). Long-term impacts of infrequent biosolids applications on chemical and microbial properties of semi-arid rangeland soil. Biology and Fertility of Soils, 42, 258-266.

Tang, J. C., Wang, M., Wang, F., Sun, Q., \& Zhou, Q. X. (2011). Eco-toxicity of petroleum hydrocarbon contaminated soil. Journal of Environmental Sciences, 23(5), 845-851.

Urbaniak, M., Wyrwicka, A., Tołoczko, W., Serwecińska, L., \& Zieliński, M. (2017). The effect of sewage sludge application on soil properties and willow (Salix sp.) cultivation. Science of the Total Environment, 586, 66-75.

Wang, J., Zhang, Z. Z., Su, Y. M., He, W., He, F., \& Song, H. G. (2008). Phytoremediation of petroleum polluted soil. Petroleum Science, 5(2), 167-171.

Wang, S., Gao, B., Li, Y., Ok, Y. S., Shen, C., \& Xue, S. (2017). Biochar provides a safe and value added solution for 
hyperaccumulating plant disposal: A case study of Phytolacca acinosa Roxb. (Phytolaccaceae). Chemosphere, 178, 59-64.

Wyszkowski, M., \& Wyszkowska, J. (2005). Effect of enzymatic activity of diesel oil contaminated soil on the chemical composition of oat (Avena sativa L.) and maize (Zea mays L.). Plant, Soil and Environment, 51(8), 360-367.

Wyszkowski, M., \& Ziółkowska, A. (2008). Effect of petrol and diesel oil on content of organic carbon and mineral components in soil. American-Eurasian Journal of Sustainable Agriculture, 2(1), 54-60.

Wyszkowski, M., \& Ziółkowska, A. (2009). Effect of compost, bentonite and calcium oxide on content of some macroelements in plants from soil contaminated by petrol and diesel oil. Journal of Elementology, 14(2), 405-418.

Wyszkowski, M., Wyszkowska, J., \& Ziółkowska, A. (2004). Effect of soil contamination with diesel oil on yellow lupine yield and macroelements content. Plant, Soil and Environment, 50(5), 218-226.

Ziółkowska, A., \& Wyszkowski, M. (2010). Toxicity of petroleum substances to microorganisms and plants. Ecological Chemistry and Engineering S, 17(1), 73-82.

Publisher's Note Springer Nature remains neutral with regard to jurisdictional claims in published maps and institutional affiliations. 